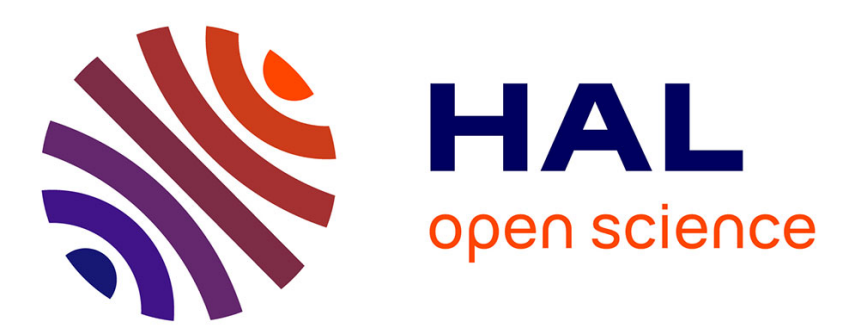

\title{
The Creative Commons licences through moral rights provisions in French law
}

\author{
Alexandra Giannopoulou
}

\section{To cite this version:}

Alexandra Giannopoulou. The Creative Commons licences through moral rights provisions in French law. International Review of Law, Computers and Technology, 2014, Special Issue: BILETA 2014, 28 (1), pp.60-80. 10.1080/13600869.2013.869923 . hal-01226877

\section{HAL Id: hal-01226877 https://hal.science/hal-01226877}

Submitted on 13 Nov 2015

HAL is a multi-disciplinary open access archive for the deposit and dissemination of scientific research documents, whether they are published or not. The documents may come from teaching and research institutions in France or abroad, or from public or private research centers.
L'archive ouverte pluridisciplinaire HAL, est destinée au dépôt et à la diffusion de documents scientifiques de niveau recherche, publiés ou non, émanant des établissements d'enseignement et de recherche français ou étrangers, des laboratoires publics ou privés. 


\title{
The Creative Commons licences through moral rights provisions in French law
}

\author{
Alexandra Giannopoulou* \\ Université de Paris II Panthéon Assas, 12 place Panthéon 75005 Paris, France \\ (Received 27 July 2013; final version received 1 November 2013)
}

\begin{abstract}
Since 2002, Creative Commons has been continuously evolving in order to create a licensing scheme that not only fulfils the needs of the author but also stays compatible with already existing national copyright laws. The extent of the respect of moral rights provisions has always been highlighted during the licences' evolution. This Article first examines whether moral rights are expressly mentioned in the licences and if so, what their treatment is. Each element of the moral rights in the French system will be considered in order to verify their compatibility with the Creative Commons licences. In this context, it will be also asserted whether some existing clauses in the licence contradict with the moral rights of authors. The Article will conclude that although a more flexible interpretation of moral rights provisions is needed when dealing with open content licences, it is essential that Creative Commons addresses the aspects of the licences that are identified as problematic in relation to moral rights. Finally, it will be demonstrated that regardless of the legal status of the licences, the authors' responsibility towards their rights is what will ultimately be the safeguard of their creations' path.
\end{abstract}

Keywords: open content licences, Creative Commons, moral rights, French law

\section{Introduction}

Creative Commons is a non-profit organization created in the United States ten years ago. Since 2002 the Creative Commons organization provides a set of standardised tools to authors in order to help them grant copyright permissions over their work. By using these tools, the authors can distribute their work publicly and decide upon the level of freedom

* Email: alex.giannopoulou@gmail.com

** This is an Accepted Manuscript of an article published by Taylor \& Francis in International Review of Law, Computers \& Technology on 02 January 2014, available online: http://dx.doi.org/10.1080/13600869.2013.869923

*** Cite as: A. Giannopoulou, The Creative Commons licences through moral rights provisions in French law, International Review of Law, Computers \& Technology, Vol. 28, Iss. 1, 2014, pp.60-80. 
granted to their licensed creation. In order to maximize 'digital creativity, sharing and innovation" Creative Commons built a set of free legal tools which constitutes 'a layer of reasonable, flexible copyright in the face of increasingly restrictive default rules'. Those legal tools are initially divided in two categories: First, a set of six licences which is designed to help authors manage the exploitation of their creations and second, the public domain tools whose goal is to facilitate authors in dedicating their works to the public domain or label and discover works that are already in the public domain. Creative Commons points out clearly in multiple occasions that its goal is not to substitute existing copyright laws, but to 'work alongside copyright'. It provides the means for the authors to make the passage from a system 'all rights reserved' to a 'some rights reserved' one.

The process of drafting the six licences in order for them to achieve the 'some rights reserved' system and a 'reasonable and flexible copyright' has proved to be a process more complex than initially estimated. Although the legal language in the licences has evolved a lot since the drafting of the first version of the licences, the functions leading to a choice of licence haven't fundamentally changed. The licensing infrastructure conceived by Creative Commons is based on the idea that choice lies in the hands of the author. This was implemented as a web interface that allows rights owners to answer a series of 'yes' or 'no' questions and at the end, suggest the licence that best fits their needs. These questions help the author define the level of freedom they want to grant to their work, by determining for example, whether modifications will be authorized in advance or whether commercial uses will be allowed for subsequent users.

The drafting of the licences had to take into account the diversity of intellectual property laws which constituted the greatest obstacle in order to ensure their enforceability to each national applicable law. The legal text of the licences was thus subject to modifications taking also into account the lack of harmonisation in many aspects of intellectual property laws on an international level. The process of modifying and redrafting the licences has resulted in the simultaneous existence of three different versions of the licences, with version 4.0 currently being drafted ${ }^{3}$. As the licences became more widely known, many different jurisdictions started a process of translating and transposing them. This process created a community of more that 70 jurisdictions having 'ported' the international licences to their national laws and thus multiplied exponentially the number of active Creative Commons licences worldwide. France began transposing version 2.0 of the Creative Commons licences according to its national intellectual property law in 2003.

During the evolution of the licences, the respect of moral rights protection of works was one of the issues most frequently raised by the Creative Commons community. In fact, the disparity of legislation among different countries caused a two-fold problem: First, there are countries that permit waivers to moral rights (such as Canada, the United 
Kingdom and the United States, i.e. common law countries) and others that qualify moral rights as inalienable and thus not susceptible to a renunciation (such as France, Germany, Greece, Italy, i.e. civil law countries). Second, the application of each moral rights' attribute varies across jurisdictions because they are adopting patterns that are more or less restrictive. Respecting both systems without excessively limiting any of them was a question of delicate wording of the licence terms.

This Article will seek to explore the compatibility of the Creative Commons licences with regards to French intellectual property provisions. The French legal system presents a particular challenge towards the Creative Commons licences because it represents the most restrictive moral rights protection system. The licences will be examined as transposed in the French legal system as well as in their generic form. Since version 4.0 is not yet finalised at the time of writing of the Article, version 3.0 is still considered to be the most current one and will serve as a standard to be examined and compared with other versions. Examples from version 4.0 are based on the drafts published online, the fourth and final draft having been published on October 2013.

The comparison between different versions of the licences will only focus on provisions that expressly or indirectly relate to the respect of moral rights. It will therefore be determined whether there exist specific clauses in the licence waiving or asserting moral rights and if so, to what degree. The examined moral rights' attributes will furthermore be divided in two categories following two criteria: the nature of each attribute as well as whether each attribute is protected by international conventions or only national laws. The first category clusters together the attribution rights and the integrity right. Both of these rights are protected by international conventions and also deal with the rights related to the life of the published work (Strömholm, 1967; Bertrand 2012). The second category includes the publication and withdrawal right which deal with the rights of the author regarding the prerogatives of the publication of the work and constitute an addition to moral rights protection 'à la française'.

\section{The unity of moral rights}

Although moral rights are part of most copyright legal systems, they contain remarkable discrepancies in their application as well as the scope of the rights they aim to protect. A minimum protection of moral rights has been introduced on an international ${ }^{4}$ as well as on a European Union level ${ }^{5}$. France goes beyond that substantive minima to provide a more complete protection of an author's moral rights. The predominance of moral rights over patrimonial ones can even be deduced from the structure of the Code de la propriété intellectuelle, which states at the first article that 'the rights of ownership of the author comprise attributes of an intellectual and moral nature as well as attributes of a 
patrimonial nature [emphasis added]' (Dufay and Pican). The droit moral, as it is perceived by the French legislator, represents the 'umbilical cord' that binds together the work and its creator ${ }^{6}$. It is the expression of the personality of the author embodied in the work that is protected by French law by this specific right. Moral rights are therefore considered to bear the characteristics of personality rights with the exception that moral rights exist only through the work created and do not constitute a right that is inherent in every human being. In that sense, they have been characterised as 'super-personality rights' (Gautier, 2012). This characteristic distinguishes how moral rights are perceived in France when compared to personality rights in other civil law jurisdictions. The droit moral is not perceived to protect the author as a person but instead aims to protect the connection that exists between the work and its author, which is considered to be an element external to the actual personality of the author.

Since its emergence in French legal theory, there is a discord whether the droit moral exists as a uniform right (droit moral) or solely exists as an expression of multiple rights (droit moraux); this mostly theoretical debate, still persists (Caron, 2007). Before the codification of the rights to the Code de la propriéte intellectuelle of 1957, the theory that described the droit moral focused on the unity of the underlying principle of the different attributes of the moral right. After the codification however, the differences between the characteristics of each attribute were highlighted (i.e. the persistence of the right after the death of the author is not a inherent characteristic of all moral rights attributes). The chapter regulating moral rights defines the right in its plural form (droit moraux), which is also in accordance with the position favoured by the European Court of Justice. The use of the plural term when referring to the French equivalent of moral rights should not discard the established unity of this right which is demonstrated by the common and unique characteristics that all its attributes bear. According to the Code de la propriété intellectuelle, moral rights are 'perpetual, inalienable and imprescriptible'. Although the article in question (L. 121-2 of the Code de la Propriété intellectuelle) expressly refers to the right of the author to enjoy respect to his name, his authorship and his work, the specified characteristics of the right are considered applied to all attributes of moral rights since the article is situated in the specific chapter of the Code.

The Berne Convention remains silent on the qualification of moral rights as inalienable or not. In fact, the only character that the Berne Convention attributes to moral rights is their autonomy. According to article 6bis, moral rights are recognised to the author 'independently of the author's economic rights, and even after the transfer of the said rights' (Ricketson, 1987). The lack of precision on the issue could be interpreted as leaving it to the discretion of national laws. A right is considered alienable when the rightsholder is given the possibility to transfer the right in question. The transfer of the right presupposes that it is waivable by the original rightsholder, and that it can be 
disconnected from him. As the French moral rights system qualifies all moral rights' attributes as inalienable, it rejects all attempts to transfer moral rights or unilaterally waive them and consequently considers every moral rights' waiver void and unenforceable.

\subsection{Contractual adjustment of moral rights in the Creative Commons licences}

Despite their inalienable nature, moral rights are often part of contractual agreements. In regards to French law, inalienability provides a certain kind of immunity to moral rights to the extent that they remain unaffected by waivers included in contracts, which are considered void. However, their inclusion in contracts is not expressly prohibited by any law and, with some adjustments to their application, are actually being permitted in the context of specific situations. Including a clause in the contract regarding the moral rights of the author serves not only to assert the prevalence and application of the author's rights over the work, but also to guide the interpretation and application of the moral rights of the work itself. According to Rigamonti, 'the function of moral rights in the contract scenario is not so much to establish absolute rights of authors in their works, but to guide contract interpretation, to establish default rules, and to set compulsory terms with respect to very specific issues in copyright contracts' (Rigamonti, 2006).

Several aspects of moral rights appear in the legal text of the Creative Commons licences during their evolution. The existing clauses related to moral rights serve to either specifically state that moral rights are not part of the licensed rights or to arrange the application of specific moral rights' attributes. The term 'moral rights' is not expressly mentioned in any of the licences up to version 4.0. This latest version of the licences specifically states that 'moral rights, such as the right of integrity, are not licensed under this Public license ${ }^{8}$. However, Creative Commons has always included clauses assuring the respect of at least the attribution right with the exception of four (now retired) out of the eleven licences in version 1.0 where the attribution element was not included. More specifically, the 'Non-commercial', 'Non-commercial- No derivatives', 'Non commercial -Share alike' and 'No derivatives' licences did not include a clause requiring attribution to the original author of the licensed work, but did not explicitly waive the right either. Corbett attributes the omission of moral rights provisions in the original versions of the licences to the existent legal uncertainty regarding the compliance of moral rights protection provided by the Berne Convention in the United States (Corbett, 2011, 521) Since version 2.0, all licences try to adjust the attribution right by providing licensees with instructions on how the author is to be properly attributed. This effort to predetermine the exact way of attribution can only be qualified as an adjustment of a moral rights' attribute and not as a 'reinforcement' to existing moral rights protection, a character attributed to the licences by Professor Rajan (Sundara Rajan, 2011b, 926). It is 
indeed difficult to see how this contractual obligation would reinforce a copyright law prerogative.

The Creative Commons licences were not drafted in order to substitute existing copyright laws. They are copyright licences and depend on the existence of copyright laws to be enforced. Creative Commons does not seek to introduce dispositions reforming copyright laws but to 'provide voluntary options for creators who wish to share their material on more open terms than current copyright systems allow' ${ }^{9}$. The licences rely on traditional norms in order to be enforced. Several 'open source' organizations as well as Creative Commons have stated: 'while public licences are generous in their permissions, the rights and remedies of copyright law remain critically important to their enforcement, 10 . The licences provide flexibility to the disposition of authors' rights, but this does not ensue that 'those who choose to license their work under conditions designed to increase innovation should [...] be penalized with inadequate protection and diminished enforcement rights. Rather, they should retain the full array of remedies that other licensors retain ${ }^{11}$. In a moral rights context this translates that where those rights are recognised, the licence will be interpreted in reference to applicable norms. The specific clauses will either assert the need for moral rights respect by users of the licensed work or (where applicable and for specific licences only) moral rights will be considered waived. A waiver of moral rights will therefore be applied in countries permitting it such as Canada, the United Kingdom or the United States but only for the specific CC0 waiver containing the clause in question, specifically waiving all rights over the work including moral rights. It is thus the licence that adapts to the local legal prerogative and not the law that bends in order to better serve the purposes of the licence. The respect of moral rights according to any applicable law, including French law, will therefore be considered inherent in every licence.

A question arises when the applicable law attributes less moral rights' protection than the licence clauses cover. The United States for example, provides copyright protection for the moral right of attribution, but only in the limited context of works of visual art. A use of a licence to a non-visual artwork creates a contractual obligation to attribute the author even if the existing copyright law does not cover that specific type of work. The harmonisation of the Berne Convention principles with the United States Copyright Act remains problematic based on its interpretation by case law (Sundara Rajan, 2011a, 137). After highlighting the need for reform of the current legislation, Professor Sundara Rajan suggests that the Creative Commons attribution clause can serve the purpose of expanding moral rights protection to areas unprotected by current legislation (Sundara Rajan, 2011a, 500; Sundara Rajan, 2011b, 926). Going as far as to proclaim an extension of moral rights protection in the United States by means of the Creative Commons licences, seems an unfortunate interpretation of the licences, as trying to introduce a 
contractual copyright protection where there is none. Notwithstanding the fact that the purpose of the licences was never to expand or replace copyright laws, the specific attribution clauses in all licences serve merely as conditions of use of the work. When a licensee violates any licence clause (including the 'attribution' clause) the licence is terminated for the specific use and thus the licensee does not have the right to use the licensed work. In that case, the licensee is liable for copyright infringement based on a use that is not substantiated by an authorisation by the author and not based on a moral rights' claim.

The first attempt to adjust attribution to the licensed work started in some of the version 1.0 licences, where the licences containing the 'attribution' element specified that the licensee 'must keep intact all copyright notices for the Work and give the Original Author credit reasonable to the medium or means ${ }^{12}$ utilised. Versions 1.0 and 2.0 present only minor wording differences in describing the way an author is to be attributed: the main prerogatives of the clause include specifying the name or pseudonym of the author, the title of the licensed works, and a description of the use this licensed work in a derivative work. In order to further clarify the attribution prerogatives, the amended version 2.5 specifies that 'if the Original Author and/or Licensor designate another party or parties (e.g. a sponsor institute, publishing entity, journal) for attribution in Licensor's copyright notice, terms of service or by other reasonable means, the name of such party or parties ${ }^{13}$ is to mentioned. This amendment was deemed necessary in order to provide a specific environment for authors to choose to give attribution directly to wikis or to public institutions such as universities etc ${ }^{14}$.

It is in version 3.0 that the licences gain a more international/ jurisdiction agnostic form. By utilising international conventions' terminology, Creative Commons makes apparent the decision to specifically include provisions about moral rights' attributes that are protected by the Berne Convention. To that end, the attribution clause becomes more elaborate and an additional clause is inserted to assert the integrity right in the way it is protected by the Berne Convention. It is stated that the licensee 'must not distort, mutilate, modify or take other derogatory action in relation to the Work which would be prejudicial to the Original Author's honour or reputation ${ }^{15}$ when distributing or creating secondary works derived from the licensed work. The French ported version however does not limit this clause to the integrity right but expands it to assert the respect of all moral rights related to the author and the licensed work ${ }^{16}$. The same wording is followed by other ported versions, such as the Australian one, stating that 'moral rights remain unaffected to the extent they are recognized and not waivable by applicable law' ${ }^{17}$. The only time that the term moral rights appears at an international / not ported version of the licences is in version 4.0, where it is used to exclude moral rights from the scope of the licences ${ }^{18}$. 
The licence continues to explain that the applicability of the attribution clause depends on the 'medium, means and context in which the Licensed Material or Adapted Material is Shared ${ }^{19}$. It is thus accepted that with regards to the work and its use, the attribution requirement can be fulfilled to any extent possible.

Although French law perceives moral rights as 'sacred' rights, it is evident that their adjustment is deemed valid and sometimes even necessary. It is through precision and adjustment that the safest application of some moral rights' attributes is ensured with regard to the nature of the work and also with regard to the wishes of the author.

\subsection{Contractual renunciation of moral rights}

Contrary to common law countries permitting a general waiver of moral rights ${ }^{20}$ similar to that of economic rights, no such waiver is considered valid under the prerogatives of French law qualifying moral rights as inalienable. According to Professor Rajan, 'limiting an author's right to choose is probably a concession to a tough bargaining environment, in which the right to waive one's rights is separated by just a hair's breadth from the expectation that one will do so' (Sundara Rajan, 2011a, 68). This rule however refers to a renunciation as an abdication of rights; it does not refer to a renunciation to exercise those rights in specific situations. The latter is permitted although freely revocable at any time, which substantially voids it of its enforceability. In order for a waiver of rights (in a specific context) to be accepted, an informed consent given by the author is necessary and therefore 'carte blanche' waivers are rejected. This particular anomaly at waivers policy among EU jurisdictions with the persistence of the unwaivable moral rights in civil law countries such as France is perceived as 'outdated, unnecessary and even counterproductive to the well-functioning of a healthy entertainment industry'. (IRTC, 1995; Grosheide, 2009, 266)

A waiver of rights is perceived as a refusal by authors to remain protected by the established by law rights, because these rights are perceived to be useless or even harmful (Lucas- Schlötter, 2002, §466). The waiver of rights is accepted only when expressed in a direct manner, it cannot be considered implied by the conduct of the author. Based on this prerogative, Creative Commons published $\mathrm{CC} 0$ which is a tool used by authors to expressly waive all their rights, even moral ones. Such a waiver is unenforceable under French law with regards to its inalienable moral rights prerogatives. In this case, the inserted fall back provision ${ }^{21}$ applies to transform CC0 into a licence. This licence will constitute a renunciation of all economic rights and the author will retain only the unwaivable moral rights to the licensed work. This fall back provision specifically includes an assertion from the author to not 'exercise any of his or her remaining 
Copyright and Related Rights in the Work ${ }^{22}$. A waiver of the exercise of moral rights does not consist an uncommon copyright practice even in France but these waivers are valid only under the condition that they are limited, precise and freely revocable (Caron, $2013, \S 253)$. The most well known example of a waiver of the exercice of a moral right is 'ghostwriting' where the original author consents that their creation be attributed to a third party. It is not considered an alienation of the paternity right since the author always reserves the option of demanding the restitution of his name. French courts have also ruled that a priori given waivers are opposed to the principle of inalienability of moral rights (Cour de cassation, $1^{\text {st }}$ civ, 28 January 2003, Bull.civ.I, n²8). In this context, the $\mathrm{CC} 0$ clause could not be perceived as an a priori consent to moral rights' infringements because of the abstraction of the clause. This part of the provision will be considered as void under French law.

The wording of the clauses relating to moral rights in all Creative Commons licences suggests that these clauses are not drafted with the intention to waive these rights. According to French law prerogatives, the clauses in question are perceived as authorisations regarding uses of the licensed work under the condition that these uses will not harm any of the moral rights of the author. Version 4.0 of the licences states that 'to the extent possible, the Licensor waives or agrees not to assert any such rights held by the Licensor to the limited extent necessary to allow You to exercise the Licensed Rights, but not otherwise ${ }^{23}$. In the context of French law the author is, according to this clause, providing an authorisation to licensees to use the licensed work, but he remains free to assert a violation over any of his moral rights over the work in question. The a priori general authorisation to use the work will not affect the author's ability to assert any moral rights violations to the licensed work.

\section{The internationally protected moral rights}

Included in the Berne Convention since 1928 and last amended in 1948, article 6bis recognizes some aspects of moral rights protection for the authors. According to Rigamonti, after several objections were raised by common law countries, the draft of the Berne Convention was "modified from protecting "moral interests" to protecting the author's "honor and reputation".' (Rigamonti, 2007, 118). The term moral rights is not explicitly used in the article and the only mention of that term is found in article 11 bis.2. The provision officially recognises two attributes of moral rights: the right of the author to claim authorship over his creation and the right of the author to protect his honour or reputation. This article embodies the minimum level of international protection of the moral rights of attribution and integrity of the author of the work. The right to be recognised as the author of a work is of demonstrated importance in the Berne Convention since it appears in multiple articles across the Convention ${ }^{24}$. The recognised 
by the Berne Convention attributes are the most widely known and accepted representations of moral rights and they are protected in all signatory countries of the Berne Convention. Despite many attempts to bring 'true harmonisation' (Grosheide, 2009 , 253) of moral rights by means of other international legal instruments ${ }^{25}$, the Berne Convention still remains the only widely adopted referenced text for moral rights protection $^{26}$. France has not been greatly influenced by the Berne Convention regarding moral rights protection, and kept its own interpretation of each attribute of moral rights. Namely, the attribution right regulates the right of the author to be attributed as the creator of his work (including the right to choose to remain anonymous or use a pseudonym). Furthermore, the integrity right 'à la française' proclaims the right of the author to oppose any modifications of the work that violate the integrity of the work. The particular interest of this last moral right attribute is that it contains an inherent discrepancy compared to the corresponding article at the Berne Convention, which protects the author from any violations to his honour and reputation and thus shifts the criteria of constituting a violation from the work to the author as a person.

The Berne Convention terminology used in all Creative Commons licences starting from version 3.0 does not mean that the licences are excluded from being subject to national laws for enforceability. The application of moral rights provisions to countries that include a broader or weaker protection than the Berne Convention's provisions remains problematic. For example, the French moral rights' protection system remains one of the more restrictive ones in the world and the Unites States provide only the minimum of protection to moral rights and only to works of visual $\mathrm{art}^{27}$. The respect of moral rights by the licences will be examined with regard to French law, notwithstanding the international convention's terminology used in the licences.

\subsection{Attribution right}

The attribution right or paternity right is one of the major prerogatives of moral rights and is protected by the French Code de la propriété intellectuelle in the article L. 121-1, recognising the right of the author to enjoy the respect to his name as well as his title regarding the creation in question. This is the positive aspect of the paternity right as another provision (L. 113-6 of the Code de la propriété intellectuelle) establishes the right of the author to remain anonymous or retain a pseudonym or even request that he not be attributed regarding a specific creation. Respecting all possible aspects of the attribution right throughout the life of a Creative Commons' licensed work can be a complicated task. And the efforts of Creative Commons to assure the respect of the right of the author to be attributed are indisputable. Notwithstanding the existing clauses, attribution practices can prove to be more complicated especially in the case of the creation of secondary works. It is in fact, unclear that licensees bringing modifications 
(regardless of their nature) to the licensed work need to also identify themselves along with the author of the original work ${ }^{28}$. The clause related to this question requires only that after modification the licensed work, and upon publication of the modified work, the licensee needs to indicate that the work is a modified version of the original one and link back to that original one ${ }^{29}$.

The right of the author to use a pseudonym is directly covered by the licences but the exercise of the right of the author to stay anonymous remains dubious. Across the different versions, the licence stated that the name (or pseudonym) of the original author is to be marked 'if supplied'. This provision was reformulated in version 4.0 of the licences to state that the licensee must indicate the name of the author 'in any reasonable manner requested by the Licensor (including by pseudonym if designated), ${ }^{30}$. The exclusion of the right of the author to remain anonymous from the licences is a possibility that has to be considered because of the difficulties in its application. In fact, the applicability of the exercise of the anonymity right is subordinated by its revocability and its precision. The abdication of the moral right of paternity is not a legally permissible option. When the author chooses to stay anonymous he retains the right to change his mind and restate his qualification as the author of the specific work. This entails inherent risks for author should they choose to apply a Creative Commons licence. The application of the paternity rights through anonymity will have to be stated in a complementary to the licence manner, since the text of the licence does not include any such provisions. The authors should also be able to provide proof about their authorship over the licensed work in order to prevent other people from appropriating their work.

The bond between the author and the work is not lost with the choice of anonymity. However, the free distribution of works under a Creative Commons licence may endanger this bond if the right precisions are not provided by the authors who choose to exercise their attribution right through anonymity. The licences that contain clauses such as 'no derivatives' or 'non-commercial uses' also exaggerate the need for the author to be identifiable. Creative Commons has in fact underlined the possibility of licensees to contact directly the author in case they need to make a specific use of the licensed work whose legality could be doubted ${ }^{31}$.

The anonymity option can prove to be problematic in the course of the life of the work even for licences with no supplementary restrictions, as seen in the case where the author of a secondary work chooses to remain anonymous but properly attributes the author of the original work. In this scenario, the latter will be falsely attributed a work that was created by another person and it will be up to that original author to contest the paternity of the work as a violation of his moral rights. French courts have ruled that moral rights also permit the author to contest the paternity of a work that does not originate from him 
(Tribunal Correctionnel de Paris, 9 May 1995). Finally, the requirement to identify each contributor to the work is compatible with the integrity right as well. The attribution of each modification to specific authors will lead to them being able to contest the use or modification of their work as not being in compliance with the 'goal' of the work. Section 4.b states that the licensee 'may not implicitly or explicitly assert or imply any connection with, sponsorship or endorsement by the Original Author, Licensor and/or Attribution Parties' in the case of reproduction of a secondary work. This clause not only covers the case of involuntary endorsement but could also be considered as a clause adjusting the attribution right of the authors of modified works. This clause has disappeared in version 4.0 and it was replaced by the option given to the author to ask to not be associated with secondary works originating from his work ${ }^{32}$.

\subsection{Integrity right}

The integrity right is recognized in the Berne Convention in order to protect the author's honour or reputation. The Berne Convention imposes a minimum level of protection, which is however subject to a more broad regulation on a national level. The level of protection of the integrity rights varies greatly among the Member States of the European Union. In fact, a study commissioned by the EU Commisssion's Internal Market Directorate- General on moral rights established that there is a great level of disparity regarding the protection of the moral right of integrity among different Member States (EU Commission, 2000; De Werra, 2009, 269). France is considered to have adopted one of the most protective regimes especially in the context of this right. The integrity right is generally seen as the 'central tenet' of moral rights jurisprudence (Netanel, 1994; Adler, 2009), and on a national level as the 'cornerstone of the French moral rights system' (Sundara Rajan, 2011a, 74). French law indeed views the right of integrity as something more broad, encompassing not only acts resulting in the harm of the author's reputation and honour (which are not even mentioned in the French equivalent) but also all mutilations that are harmful to the integrity of the work in itself. In fact, the first mention of the integrity right in France (droit au respect à l'œuvre) appeared when a judge rejected the modification of a work for which the person had acquired the exploitation rights (Tribunal civil de la Seine, 17 August 1814: Renouard, 1838-1839; Gavin, 1960; Sirinelli, 1985). Professor Gautier makes a distinction between an 'absolute respect' of the integrity right in the case of a use of a work in its original, unmodified form and a 'relative respect', in the case of a modification of a work (Gautier, 2013). It is therefore possible to violate the integrity right of a work not only by means of modification but also by using the work in its intact form. The integrity right in the context of French law acts as a safeguard preventing any distortions to that work that do not have the express approval of the author but also any uses of the work in an unmodified, original version. Thus, the French version of the integrity right 'makes sure that the work is and remains 
as the author has created it so that no one else shall have the right to change it in any manner irrespective of whether these changes improve or negatively impact on the author's honor or reputation' (De Werra, 2009, 269). The French Cour de Cassation has elevated the integrity right to a 'public policy principle' (ordre public) and declared its inalienability by affirming that all waivers of the integrity right will be considered null (Cour de cassation $1^{\text {st }}$ civ., 28 January 2003). The practical implication of the integrity right in French Courts attributes the burden of proof to the person making the claim, the appreciation of the claim being subject to the interpretation of the facts on a case-by-case basis.

The Creative Commons licences affirm the requirement to respect the integrity right of the author, in the form that it is present in the Berne Convention. The licences thus require from the licensee to "not distort, mutilate, modify or take other derogatory action in relation to the Work which would be prejudicial to the Original Author's honour or reputation'. In order to examine the extent of the applicability of the integrity right to Creative Commons licensed works, it is important to make a distinction between the licences that allow modifications to the licensed work and the licences that don't provide such liberties to the licensees.

\subsubsection{A licence to use but not to modify the work}

Certain Creative Commons licences, specifically the ones containing the 'Non derivatives' clause, do not allow modifications to the licensed work. All the licences however authorise the licensee to 'Reproduce the Work, to incorporate the Work into one or more Collections, and to Reproduce the Work as incorporated in the Collections' as well as 'to Distribute and Publicly Perform the Work including as incorporated in Collections ${ }^{33}$.

The same clause also permits all modifications that are 'technically necessary' in order to exercise the above rights. This last clarification is well justified by the need to facilitate distribution of the licensed work. However in practice, the authorisation to proceed to modifications that are 'technically necessary' does not guarantee immunity against violations of the integrity right of the author. The interpretation of this authorisation needs to be strict in order to distinguish cases where technically necessary modifications result in a distortion of the licensed work. This interpretation also needs to take into account the nature of the licensed work. In fact, alterations in a work often take place in the course of its life without them being harmful to its integrity. There are for example some works that are created in an ephemeral form or works whose goal is to not stay intact forever but be subject to the changes caused by time or use. When it comes to digital reproduction of works, some functions considered technically necessary result in lowering the quality of the work and could constitute violations of the integrity right of 
the author. For instance, the Tribunal de Grande Instance of Paris has concluded that streaming results in the lowering the quality of the work, especially in movies, constituting a violation of the integrity right of the work (Tribunal de Grande Instance of Paris, 13 July 2007).

However, the a priori prohibition to create derivative works does not constitute a safeguard to the integrity right of the author. As it is pointed out by Professor Rajan, 'even if the user of the work did something less dramatic than the creation of a derivative work, but altered the original work-for example, if he shared a piece of music from which, one of the stanzas of the song had been removed- this could certainly qualify as a violation of the moral right of integrity. The integrity of the work would be violated even though a derivative work would not necessarily have been created' (Sundara Rajan, 2011a, 501). It is not uncommon that the integrity right of the work be violated even without the creation of a derivative work. In fact, a violation of the integrity right of the author can be caused by the association of the work with other works even without modifying the original work. However, the 'non-derivatives' clause does not in itself constitute an effort from Creative Commons to assert the respect of the integrity right. This clause has been interpreted as 'a distorted reflexion of the moral right of integrity' (Sundara Rajan, 2011a, 501) but in fact the licence proclaims the respect to the author's honor and reputation in a separate clause. The assertion of the respect of the moral right of integrity seems justified even in the case of licences restricting modifications of the work or creation of secondary works based on the licensed one ${ }^{34}$.

\subsubsection{A licence to use and modify the work}

The creation of a derivative work disturbs the delicate balance between the freedom of creation and the respect of the integrity right of the author of the original work. In fact, the judge in a recent case involving Les Misérables by Victor Hugo examined that balance. According to the facts of the case, one of the heirs of Victor Hugo wanted to prevent the publication of a sequel to the novel but the claim was ultimately denied as the courts concluded that a public domain work is open for adaptation, according to the freedom of creation. The court decided that any harm to the integrity right needs to be proven by the heirs who would have to convince the court about the position that the author would have taken regarding the adaptation (Cour de cassation, 30 January 2007). As it was previously stated, French courts have rejected the idea of a 'carte blanche' authorisation to modify works and nullified contract clauses that contain them on the basis of the inalienability of the moral right of integrity. In the case of the Creative Commons licences authorising modifications to the licensed work, the authorisation granted to the author is not to be perceived to the expense of the right of integrity. According to the licence clauses, the author accepts that modifications are made to the 
licensed work, as long as these modifications do not harm the integrity of the author or the nature of the work.

The appreciation of the validity of a claim regarding a violation of the integrity right can be facilitated by resorting to the theory of purpose. According to this theory, determining the goal of the creation and distribution of the work is the significant key in appreciating the constitution of a violation of the integrity rights. The determination of the goal of the creation of a work is also important in judging whether the freedom of creation of the secondary author should be limited with regards to respecting the integrity right of the author of the original work. The application of the theory of purpose at the Creative Commons licences can prove to be a precarious solution and somewhat limited to the first steps of the life of the licensed work. In fact, the purpose of creation of the work is not always discernable and following the path of the licensed work along possible redistributions and modifications, that original purpose of the creation of the work risks of becoming elusive. The incompatibility between the free dissemination of works and the integrity right of the author seems difficult to balance. However, it seems to pose less of a threat in the case of the licences that authorize modifications under the 'share alike' condition. It is under the security of this clause that the author is safe from being 'the victim of his own generosity' (Clément- Fontaine, 2006, §184; 2009). The 'share alike' clause will be interpreted as representing the informed decision of an author to freely distribute a work. According to Clément- Fontaine, a softer application of the integrity right of the author as well as all that of all subsequent authors and their creations will then seem justified (Clément- Fontaine, 2006).

The extent of the applicability of the integrity right is put under a different perspective as for the licences not containing the 'share alike' clause. The terrain of the appreciation of the integrity right has extended to the behaviour of the author. According to this appreciation, the safeguarding of the exercise of moral rights lies in the control for abusive exercise of the rights. However, determining an abusive use of a moral right attribute is to be used with caution and should not be confused with an excessive use of a right. The authorisation to modify implies a freedom of creation for subsequent authors but it is the integrity right that moderates the subsequent authors' liberty. The motivation of the author to create a specific work and to make it freely available is not necessarily related to the fact that an attack to the integrity right is constituted. When it comes to works that have been subject to multiple and diverse modifications during the course of their existence, it seems even harder to make the distinction between a legitimate and an abusive evocation of the integrity right by a judge.

Finally, since the licensing of a work under a Creative Commons licence has as a primary goal the free dissemination of that work, its free nature embodied by the author through 
the licence should be taken into consideration when appreciating the constitution of a violation of an integrity right. The inalienable nature of the integrity right should not be doubted in the context of the licences, which do not try to suppose a renunciation of that right. However, the application of the integrity right to Creative Commons licensed works even within the strict protection of this right in the context of French law has to be accommodated according to the free nature of this work.

\section{The French addition to the moral rights protection}

The two remaining moral rights attributes in French law are not protected by the Berne Convention, although the withdrawal right is not completely overlooked ${ }^{35}$. However, this does not diminish their importance because the internationally protected moral rights are not characterised as the only existing moral rights. The silence of the Convention on the issue is interpreted as leaving a discretionary power to national laws to include other moral rights in addition to the conventional ones. The provisions in French law adding two moral rights relate these rights to the publication of the work. They consider the author as the 'master' of the fate of the work, deciding not only if, when and how the work will be published but also whether it can be retired from a specific publication agreement. While not so prominent on an international level, the divulgation right and the withdrawal right occupy a place as important as the aforementioned attributes of moral rights namely the attribution and the integrity right in French law. It will be examined whether the divulgation or otherwise known as publication right is restricted by some of the Creative Commons licences' provisions as well as how can the withdrawal right be applied to the licences.

\subsection{Publication right}

This specific moral right attribute refers to the exclusive right given to the author to decide when and how his creation will be published and communicated to the greater public. The publication right is a historic moral right in France as it was first introduced by the Cour de cassation with the famous Whistler case in 1900 (Cour de cassation, 14 March 1900). The Berne Convention makes only an indirect mention of this right; it 'partially secures the right in provisions like articles 10 and 10bis which effectively limit their exemptions to published works' (Goldstein and Hugenholtz, 2012, §10.3). The author is free to decide whether the work will be published as well as the modalities of the exercise of the publication right. It is not disputed that licensing a work under a Creative Commons licence constitutes an exercise of the publication right but the conditions of the exercise of that right raise certain issues. When the author of a work licenses it under a Creative Commons licence, he is exercising his publication right in its 
full extent and he is free to impose any conditions to the distribution and reuse of the work. The same does not apply however for subsequent authors who are willing to access and use the licensed work because some of the clauses implicate limitations to the publication of secondary works.

Each licence, according to the clauses included, limits the publication right of subsequent authors in various levels. It is for example clear that the 'Attribution' and the 'Attribution- No derivatives' licence do not limit the subsequent users who are free to distribute and, in the case of the first licence, modify the licensed work without having to abide by specific clauses regarding the way of the publication of the work. The clauses affecting the way the original licensed work will be used as well as its derivatives are the 'no commercial uses' clause and the 'share alike'. It is not clear, whether these two clauses excessively restrict the secondary authors' moral right of publication since by accepting this licence, the licensee and potential subsequent author can decide when to publish his creation but not how. However, the conditions of the licence have to be applied only in case that the author decides to publish his work since the publication right gives the option to the author to not publish it and oppose to any publications against his will.

\subsubsection{Licences containing the 'non commercial' clause}

Three of the Creative Commons offered licences contain a clause that permits the author of the licensed work to reserve any uses of the work that have a commercial purpose. It is thus not allowed for anyone to make profit from the licensed work without the author's express authorisation. The clause is not viewed as illegal from the original author's point of view since it falls under his publication right to decide on how the work will be distributed to the public. It is also not an uncommon practice in copyright contracts for authors to impose conditions along with an authorisation to use the work in question. The law establishes a dependent relationship between the original work and its derivatives by asserting that the rights of the author of a derivative work are limited by the exercise of the rights of the author of the pre-existent work (L. 113-4 of the Code de la propriété intellectuelle).

In this context, the author of the licensed work imposes on subsequent authors the condition to refrain from any commercial exploitation of the work when using it. It is in fact within the range of the rights of the original author, to put restrictions of economical nature to the publication of derivative works. Such a clause can be accepted on the basis of the dependent relationship of the rights of the secondary author to the rights of the first author. From a contractual point of view, the clause constitutes a prerogative that has to be accepted in order for the subsequent author to be authorised to use the licensed work. 
Creative Commons is frequently criticised for using the 'non commercial' clause without providing any more clarifications regarding its meaning and the uses that it includes. The criticism derives from both advocates of free culture who believe that the clause is too vague, ambiguous and derives from the 'rightsholders' fear of giving up their copy monopolies on commercial use ${ }^{36}$. There exist multiple interpretations as to what consists or not a commercial use and to this end, Creative Commons issued a report in 2009 based on how people interpret a commercial and non-commercial use ${ }^{37}$. This report however does not constitute a norm but only serves as a guideline for both authors and users. The purpose of the Article is not to criticise the choice of Creative Commons to include a 'non commercial' clause as an optional element for the licences but to examine how the implemented clause will eventually affect the publication right of authors.

The disparity of interpretation of the clause in question between the author and the licensees is what puts the actual consent in question. For this reason, what seems important is not only for Creative Commons to stipulate which uses are considered commercial ones but also to bring more clarity to the contract regarding the wishes of the licensor. What is important for the acquisition of an informed consent from the licensee's part is to sufficiently clarify which uses would constitute a non-authorized use. Since there is no legal source to settle the issue, the interpretation will vary according the work and the original author licensing it with a NC licence. The role of Creative Commons to that matter can only be complementary in order to provide sufficient information to the potential licensor as to the need to clarify that notion towards potential downstream users.

Courts have accepted various restrictions in regards to restricting the publication terms of a derivative work in order to accommodate the rights of the author of the original work. These restrictions however, need to be sufficiently accurate in order to delimitate the level of authorisations granted. The constitution of an informed consent of the licensee and subsequent licensor can be achieved when the interpretation of the clauses of a licence reflect the wishes of the author regarding his specific work. Some national collecting societies for example, including the French SACEM, have clarified how a commercial use is perceived and hence every musician adhering to them will be subject to this interpretation regarding a work that is under a Creative Commons licence.

\subsubsection{Licences containing the 'share alike' clause}

Two licences exist in the set of the Creative Commons licences, making sure that the liberty granted to the work is sustained throughout its path. The 'share alike' clause serves that purpose. Whenever a licensee accepts a licence containing the 'share alike' 
clause, he is free to redistribute or modify the licensed work under the condition that he will grant the same level of liberties to all subsequent works.

By creating a secondary work, the rights of the secondary author obtain a dependent nature that sometimes clashes with the rights of the first author. More specifically, the publication right of the secondary author is 'amputated' by the acceptance of the 'share alike' clause. This acceptance should not however be viewed as a renunciation of the author's right, because he retains the right to publish the work. The 'share alike' clause should be interpreted as a pre-determination from the secondary author of the prerogatives governing the publication of his work. It has to be noted that the 'share alike' clause does not include an obligation to publish the derivative work. The secondary author remains completely free in deciding to communicate his work to the public or not. In the case the publication right is not exercised, the 'share alike' clause does not have to apply to the derivative work, since this condition depends specifically on publication.

On the one hand, the obligation imposed to subsequent authors to publish their work under an equally free licence is acceptable on a theoretical basis, because it is imposed in order to preserve the freedom to licensed works throughout the course of their path and contribute to the creation of more free works. On the other hand, the legal implications related to this clause prohibit it from being unanimously accepted. According to the reasoning regarding the 'non commercial' clause, imposing to all subsequent authors to distribute their derivative works under the same licence or a licence equally permissive can be seen as a partial renunciation of the publication right as to how the derivative work will be distributed. The right of the author to impose contractual restrictions regarding the prerogatives of distribution of a derivative work is justified by the dependent relationship of the rights of the two authors. For this reason as well as because of the inalienability of the publication right, the 'share alike' clause is not viewed as a renunciation of the moral rights of the author, although some authors persist in their belief that this clause constitutes a violation of the publication right of the author (Lucas, 2012). According to the dominant belief however, the author of the secondary work remains free in his choice of whether the work will be disclosed to the public or not.

A contractual imposition of the distribution of the derivative work is not apparent at the wording of the licences ${ }^{38}$. A coercive distribution is not the goal of the law, and a contractual obligation can only be accepted in the case of an exclusive licence. In fact, when the author decides to exclusively authorise a specific adaptation of a work, it is because he wants to see that work distributed and only in this sense would a contractual obligation to exercise the publication right make sense. Professor Sirinelli proposes the application of the 'theory of the cause', meaning deciphering the actual will of the author at the moment the authorisation takes place in order to deduce an obligation or not for the 
secondary author to exercise the publication right (Sirinelli, 1985, 248). The Creative Commons licences are non-exclusive licences and as such, the 'share alike' clause cannot be interpreted as constituting an inherent contractual obligation for the secondary author to communicate his derivative works to the public.

\subsection{Withdrawal right}

The withdrawal right is further divided in two rights according to French law: the right of revocation or withdrawal and the right of repentance or alteration. The first one defines the right of the author to unilaterally cease the contract regarding the exploitation of a specific work. The second one translates as the right of the author to change his mind and make further changes to the work but it only affects the publication contract indirectly.

This is a very rarely used aspect of moral rights and it represents the care taken by the legislator to protect the authors who were considered to be the weak party of a contractual deal, against excessive contractual agreements. Its other particularity is the fact that it is the only moral right whose exercise is subordinated by compensation of the other party for the damages caused. It is exactly because of the economical nature of the withdrawal right that authors are not keen on using it. The motivation of the legislator behind this provision was in fact to prevent careless or abusive use of this right and minimize the insecurity in contractual agreements.

The question arising is how secure can a licence that authorizes use, modifications and redistribution of a work be, when authors can unilaterally choose to exercise their withdrawal right. Renunciation of this right is not possible; it is only possible in software where the law has specified that the withdrawal right cannot be applied. All Creative Commons licences are self-proclaimed as perpetual for the duration of the protection granted by copyright laws. The irrevocable nature that Creative Commons attributed to the licences is not compatible with the withdrawal right. However, the author can choose to stop to distribute the work under the chosen Creative Commons licence under the condition that all existent copies and uses of the work will not be affected and the retraction will take effect only for future uses. The practice of this prerogative is more problematic than it originally seems because it is not easy for users to deduce the exact date of the decision of the author to retract the specific Creative Commons licence from a work, causing controversies at the Creative Commons community. For example, Flickr offers the possibility for authors to put their work under a Creative Commons licence of their choosing. There are however many incidents where authors arbitrarily inter-change between licences causing insecurity to users willing to use the licensed work. 
The withdrawal right is firstly subordinated by the effective retraction of all distributed copies of the work. The application of this condition to the Creative Commons licences is difficult because of the minimum level of liberty conceded by all the licences, which is the liberty to use and distribute the work. It seems almost impossible for the author to make sure that he has tracked down and retracted all copies of the work. In fact, this task has already been identified as problematic in the case of digitally reproduced works. When the retraction takes place, a claim of an abusive use of the right may be laid by affected licensees but this claim needs to be sufficiently justified. In that case, the question shifts to whether choice of the author to retract the Creative Commons licence for a more restrictive copyright licence qualifies as exceeding the purpose of the creation of the withdrawal right. The answer may vary according to the nature of the licence that is being revoked. The abusive exercise of the withdrawal right could be appreciated differently for the revocation of the 'Attribution' licence than for the 'Attribution-Non derivatives- Non commercial' licence. The general rule should be that the more liberal the choice of licence is, the more difficult it is for the withdrawal right to be justified.

The second condition of the exercise of the withdrawal right is the compensation of the damaged parties. The application of this condition to a Creative Commons licence creates the necessity to identify the persons having distributed or used the work and thus accepted the licence. This condition constitutes the only moral rights' attribute demanding compensation as a sine qua non condition for its exercise. The fulfilment of this condition is particularly problematic in practice for the Creative Commons licences and specifically for works that have been subject to many modifications. It is difficult to estimate the amount of damage each person has suffered by the retraction of the licensed work and consequently estimate the compensation to be attributed to them. The complexity of this estimation is one of the main claims for excluding the application of the withdrawal right from all open content licences.

The final condition for the exercise of the withdrawal right is the 'priority' condition that establishes safeguard for all contracting parties. It is in fact expected that if the author decides to redistribute the work being retracted, it is the former contracting party that has a priority right over the distribution and the author has an obligation to first turn to that party before exploring other options. This prerogative seems harmless for Creative Commons. However the question that arises is whether the author is obligated to return to the former used licence or would any licence granting the same liberties satisfy the condition. The diversity of the clauses of the various existing open content licences prompts for a conclusion that the same licence should be used. However, in the case of the choice of a different licence for the work, it is only a matter of how the public will receive the newly licensed work and who will have a claim to contest the choice of the licence on the basis of the 'priority' condition of the withdrawal right. 
Notwithstanding the legally established 'priority' condition, the licences containing a 'share alike' clause will also have the same result. Even if the 'priority' principle did not exist by law, the author is required by the licence containing the 'share alike' to redistribute any derivative work under the same or an equivalent licence. In this context, the author of the secondary work is limited at his exercise of the withdrawal right because of the acceptance of this clause, which is moreover, the only way to have access to the main work.

The withdrawal right includes the retraction of all copies of the licensed work but it is not yet clear whether that retraction includes the retraction of every authorisation given to modifications of the work. This point is of particular interest to the Creative Commons licences since most of them include a general authorisation for interested parties to modify the licensed work. The dependent relationship between the original work and its subsequent modifications is already underlined and according to this prerogative, the rights of the secondary author have to be sacrificed in order for the original author to practice his withdrawal right. The interpretation of the withdrawal right as the obligation to retract all derivative works related to the licensed work will be the Achilles' heel of the licences since it will contribute to an insecurity from the users, giving a precarious and temporary nature to the licensed work.

The second aspect of the withdrawal right, namely the right of repentance or alteration, could be easily exercised by the author as authors are always entitled to alter the licensed work. Compensation is also necessary for the exercise of the right of repentance. It is based on the fact that the object of the agreement, meaning the licensed work, has been subject to modifications since the moment of the agreement. When it comes to licences authorising modifications in advance, the work is already in a more flexible position and it has attained a more evolving nature. The author can also freely modify the works subject to a licence not authorising modifications in advance. However, in order to ensure a contractual security, it seems advisable to signal the modified version of the work originating from the author. This is also part of the licence terms that expect from the licensee to 'indicate if [he has] modified the Licensed Material and retain an indication of any previous modifications, ${ }^{39}$.

Finally, it is necessary to identify modified versions of the original work in order to avoid erroneous attributions referring to the older version of the work but linking to the modified one. This is why it is considered best to retract the older version of the work in order to avoid the sentiment of insecurity to contractual transactions regarding erroneous attributions. However, when the right of repent is accompanied by the retraction of the 
older version of the work, then it is no longer an issue of that right but of the withdrawal right.

\section{Conclusion}

This Article demonstrated to what extent the moral rights provisions of French law can be respected by Creative Commons licences. Although some scholars have expressed fear that the restrictions of French law could constitute a danger to the application of open licences in France (Lucas, 2012, § 876; Vivant and Bruguière, 2012), it has been demonstrated that the Creative Commons licences seek to respect moral rights prerogatives and achieve that goal but not to its fullest extent according to the demanding French standards.

Considered as international licences throughout their evolution, the Creative Commons licences demonstrate a growing tendency to acknowledge moral rights or at least those aspects of moral rights that are specifically recognized in the Berne Convention. However, since the licences are constructed in a way to not substitute but be applied as a supplement to intellectual property laws, a mutual respect is necessary.

From the moral rights' point of view, the application of a more flexible interpretation when dealing with open content licences would contribute to the undisturbed creation, distribution and reuse of more free works. The rigidity of the definition of a work is being overturned by the principle of collaboration and contribution to the evolution of creation and ultimately, culture. It is also necessary on the other hand, that the licences are restructured and their language re-evaluated in a manner that helps authors to assure the respect of all the prerogatives of the moral rights. The guiding principle for reformulating the licences should continue to focus on the informed choice of the author. This choice needs to be supported by accurate terms that respect the rights of all authors contributing to creations since it is each author that is considered the cornerstone of the free movement.

Finally, the author constitutes the ultimate safeguard for assuring that moral rights are respected by the licensees. However, 'punishing' licensees in order to serve their ephemeral needs will not help authors assert that respect. Since most disputes are usually resolved between parties and not by court, these behaviours could end up devaluing the licences as they lose their binding nature in the eyes of the users.

\section{References}

Adler, A. M. 2009 ‘Against Moral Rights’, California Law Review, Vol. 97, p. 263 
Bertrand, A. 2011-1012. Droit d'auteur, Dalloz Action

Caron, C. 2013. Droit d'auteur et droits vosins, LexisNexis, $3^{\text {rd }}$ ed.

Caron, C. 2007. 'Droit moral ou droits moraux', Les Petites Affiches, n²44, p. 28

Clément- Fontaine, M. 2006. Les œuvres libres, Université de Montpellier I

Clément- Fontaine, M. 2009. JurisClasseur Propriété littéraire et artistique, LexisNexis Fasc. 1975 : L'œuvre libre

Comp. International Communications Round Table (IRTC), 1995. 'Response to EC Green Paper on Copyright and Related Rights in the Information Society, Section VII: Moral rights"

Corbett, S. 2011. 'Creative Commons Licences, the Copyright Regime and the Online Community: Is There a Fatal Disconnect?', The Modern Law Review, Vol. 74, Issue 4, pp. 503-531

Creative Commons, 2009. "Defining "Noncommercial" A Study of How the Online Population Understands "Noncommercial Use".': http://mirrors.creativecommons.org/ definingnoncommercial/Defining_Noncommercial_fullreport.pdf

De Werra, J. 2009. 'The moral right of integrity' In Research handbook on the future of EU copyright. Cheltenham, UK : E. Elgar, p. 267-285

Dufay, J. and Pican, X. 2004. 'The erosion of the moral right: comparison France- United States', International Business Law Journal, p.461-468

EU Commission, Internal Market Directorate, 2000. Report 'Moral rights in the context of the exploitation of works through digital technology': http://ec.europa.eu/internal_ market/copyright/docs/studies/ etd1999b53000e28_en.pdf

Gautier, P.Y. 2013. Propriété littéraire et artistique, Presses Universitaires France, $8^{\text {th }}$ ed.

Gavin, G. 1960, Le droit moral de l'auteur dans la legislation et la jurisprudence française, Dalloz

Goldstein P. and Hugenholtz, B. 2012. International Copyright. Principles, Law, and Practice, Oxford University Press, $3^{\text {rd }}$ ed.

Grosheide, W. 2009. 'Moral rights' In Research handbook on the future of EU copyright. Cheltenham, UK: E. Elgar, p. 242- 266

Lucas, A. 2012. Traité de propriété littéraire et artistique, LexisNexis 
Lucas- Schlötter, A. 2002. Droit moral et droits de la personnalité: étude de droit comparé français et allemande, Presses universitaires d'Aix-Marseille

Netanel, N. 1994 'Alienability Restrictions and the Enhancement of Author Autonomy in United States and Continental Copyright Law', Cardozo Arts \& Entertainment Law Journal, vol. 12:1, p. 37

Renouard, A.-Ch. 1838-1839. Traité des droits d'auteur dans la literature, les sciences et les beaux-arts, Jules Renouard, Paris, vol.2

Ricketson, S. 1987. The Berne Convention for the protection literary and artistic works: 1886-1986, Queen Mary College, University of London, Center for Commercial Law Studies, Kluwer

Rigamonti, C.P. 2006. 'Deconstructing Moral Rights', Harvard International Law Journal, Vol. 47, n², p.353-413

Rigamonti, C.P. 2007. 'The conceptual transformation of moral rights', The American journal of comparative law, Vol. 55, No. 1, p. 67-122

Rousselet, M. 1962. 'Le droit moral de l'auteur', Revue des travaux de l'Académie des sciences morales et politiques, Sirey, $1^{\text {st }}$ semester, p. 108

Strömholm, S. 1967. Le droit moral de l'auteur, Stockholm, vol. II, 1

Students for Free Culture, 2012. 'Stop the inclusion of proprietary licenses in Creative Commons 4.0' http://freeculture.org/blog/2012/08/27/stop-the-inclusion-of-proprietarylicenses-in-creative-commons-4-0/

Sundara Rajan, M. 2011a. Moral Rights, Oxford University Press

Sundara Rajan, M. 2011b. 'Creative Commons: America's Moral Rights?' Fordham Intellectual Property, Media \& Entertainment Law Journal, Vol. 21, p. $905-969$

Vivant, M. and Bruguière, J.-M. 2012. Droit d'auteur, Dalloz, $2^{\text {nd }}$ ed.

\footnotetext{
${ }^{1}$ See "Our mission", available at: https://creativecommons.org/about

2 http://wiki.creativecommons.org/FAQ\#How_do_CC_licences_operate.3F

${ }^{3}$ The latest version 4.0 draft of the licences was published on 15 October, 2013. All drafts of version 4.0 of Creative Commons licences are available at the wiki created specifically for the discussion of the drafting of the licences: http://wiki.creativecommons.org/4.0_Drafts [last accessed: 29 October 2013]

${ }^{4}$ See article 6 bis of the Berne Convention
} 
${ }^{5}$ While Recital 19 of Council Directive 2001/29/EC 'on the harmonisation of certain aspects of copyright and related rights in the information society' excludes moral rights from its scope and makes reference to national laws and the Berne Convention, there are mentions to some attributes of moral rights: see for example article 5(3)(d) referring to the right to be attributed.

${ }^{6}$ It is worth noting that, in the similar to the French perception of moral rights, Greek law defines the moral right of the author as the right to protect the personal connection created between him and the work.

${ }^{7}$ Phil Collins v Imtrat Handelsgesellschaft $\mathrm{mbH}$ and Patricia Im- und Export Verwaltungsgesellschaft mbH and Leif Emanuel Kraul v EMI Electrola GmbH, joined cases C-92/92 and C-326/92, ECR 1993, I-5145.

${ }^{8}$ Section 2(b)(1) of all versions 4.0 licences [last accessed: 29 October 2013]

9 Policy statement by Creative Commons issued on October 16th, 2013, available at https://creativecommons.org/about/reform. This statement however continues to express the pressing need for copyright reform: 'CC licenses are not a substitute for users' rights, and CC supports on going efforts to reform copyright law to strengthen users' rights and expand the public domain.'

10 Brief of Amici Curiae from Creative Commons et. al. on p. 15 after Jacobsen v Katzer 535 F.3d 1373 [2008] (Fed Cir (US))The Amici can be viewed here: <http://jmri.sourceforge.net/k/docket/cafc-pi1/ccc_brf.pdf $>$ last accessed: 25/ 10/2013

${ }^{11}$ id., p. 17

${ }^{12}$ See Section 4.b of the Creative Commons licences, for example the 'Attribution 1.0 Generic' licence:

$12 \mathrm{http} / / /$ creativecommons.org/licenses/by/1.0/legalcode

${ }^{13}$ See Section 4.b of version 2.5 of the Creative Commons licences, for example the 'Attribution 2.5 Generic' licence: $\mathrm{http}: / /$ creativecommons.org/licenses/by/2.5/legalcode

${ }^{14}$ The amendment is announced and explained by the general counsel at the time, Mia Garlick. http://lists.ibiblio.org/pipermail/cc-licenses/2005-May/002315.html (accessed 26 July 2013)

${ }^{15}$ See Section 4.c of the Creative Commons licences, for example the 'Attribution 3.0 Unported' licence: http://creativecommons.org/licenses/by/3.0/legalcode

${ }^{16}$ See Section 4.d of the French version of the Creative Commons licences, for example 'Attribution 3.0 France': 'si l'Acceptant Reproduit, Distribue ou Représente l'Euvre en elle-même, ou au sein d'une Adaptation ou d'une Collection, il doit respecter les droits moraux du Titulaire de Droits Originaire' http://creativecommons.org/licenses/by/3.0/fr/legalcode

${ }^{17}$ See Section $4 \mathrm{C}$ of the Australian version of the Creative Commons licences, for example 'Attribution 3.0 Australia': http://creativecommons.org/licenses/by/3.0/au/legalcode

${ }^{18}$ See Section 2.b(1) of the latest draft of the Creative Commons licences, for example 'Attribution 4.0 International', stating that 'moral rights O...are not licensed under this Public License': http://staging.creativecommons.org/licenses/by/4.0/legalcode [last accessed: 29 October 2013]

${ }^{19}$ See Section 3.(a)(2) of the latest draft of the Creative Commons licences, for example 'Attribution 4.0 International': http://staging.creativecommons.org/licenses/by/4.0/legalcode [last accessed: 29 October 2013]

${ }^{20}$ See art. 106A of the Copyright Act of the United States: '(moral) rights may be waived if the author expressly agrees to such waiver in a written instrument signed by the author. Such instrument shall specifically identify the work, and uses of that work, to which the waiver applies, and the waiver shall apply only to the work and uses so identified' and art. 48 of the British Copyright Act of 1988: '(moral rights) may be waived by consent'.

${ }^{21}$ See art. 3 of the 'CC0 1.0 Universal': http://creativecommons.org/publicdomain/zero/1.0/legalcode [last accessed: 29 October 2013]

${ }^{22} I d$

${ }^{23}$ See Section 2.b(1) of the latest draft of the Creative Commons licences, for example 'Attribution 4.0 International: http://staging.creativecommons.org/licenses/by/4.0/legalcode [last accessed: 29 October 2013]

${ }^{24}$ See for example art. 10.3, 10bis.1. See also art. 7.3 and 15.3 of the Berne Convention for anonymous and pseudonymous works. 
${ }^{25}$ Article 9 of the Agreement on Trade-Related Aspects of Intellectual Property Rights (TRIPS) expressly excludes the moral rights protection of the article 6bis of the Berne Convention from its application.

${ }^{26}$ Also, the more recent WIPO Performances and Phonograms Treaty of 1996 requires in Art 5(1) that member States provide protection for the moral rights of performers.

${ }^{27}$ Copyright Act 1976 (US),y106A(a).

${ }^{28}$ The equivalent clause (2.2) of the Art Libre licence, states that the attribution process requires that the licensee specifies 'the names of the author(s) of the originals, including yours if you have modified the work': http://artlibre.org/licence/lal/en

29 'indicate if You have modified the Licensed Material and retain an indication of any previous modifications' See section 3.(a)(1)(B) of the latest draft of the Creative Commons licences, for example 'Attribution 4.0 International': http://staging.creativecommons.org/licenses/by/4.0/legalcode [last accessed: 29 October 2013]

${ }^{30}$ See Section 3.(a)(1)(A)(i) of the latest draft of the Creative Commons licences, for example 'Attribution 4.0 International: http://staging.creativecommons.org/licenses/by/4.0/legalcode [last accessed: 29 October 2013]

${ }^{31}$ In the case of photos, a platform such as Flickr can be a solution to establish contact with the author regardless of the status of the work.

32 'If requested by the Licensor, You must remove any of the information required by Section $3(a)(1)(A)$ if reasonably practicable' See Section 3.(a)(1)(3) of the latest draft of the Creative Commons licences, for example 'Attribution 4.0 International: http://staging.creativecommons.org/licenses/by/4.0/legalcode [last accessed: 29 October 2013]

${ }^{33}$ See section 3.a and 3.b of the 'Attribution- Non derivatives 3.0 Unported' Creative Commons licence: http://creativecommons.org/licenses/by-nd/3.0/legalcode

${ }^{34} \mathrm{http} / / /$ wiki.creativecommons.org/FAQ\#What_happens_if_I_offer_my_work_under_a_Creative_Common s license_and_someone_misuses_my_work.3F

${ }^{3 \overline{5}}$ See Appendix art.II.8 and III. $4 \mathrm{~d}$.

${ }^{36}$ The most widely read critique of the NC term is 'The Case for Free Use: Reasons Not to Use a Creative Commons -NC License' available at: http://freedomdefined.org/Licenses/NC See also 'Stop the inclusion of proprietary licenses in Creative Commons 4.0', a critique by the Student for Free Culture available at http://freeculture.org/blog/2012/08/27/stop-the-inclusion-of-proprietary-licenses-in-creative-commons-4-0/ [last accessed: 29 October 2013]

${ }^{37}$ Study conducted by Creative Commons: "Defining "Noncommercial" A Study of How the Online Population Understands "Noncommercial Use".' published at 14 September 2009, available at: http://mirrors.creativecommons.org/defining-noncommercial/Defining_Noncommercial_fullreport.pdf

${ }^{38}$ See section 4.c of the Creative Commons licences, for example the 'Attribution- Share alike 3.0' licence: 'if You Distribute, or Publicly Perform the Work or any Adaptations or Collections...': http://creativecommons.org/licenses/by-sa/3.0/legalcode

${ }^{39}$ See Section 3.(a)(B) of the latest draft of the Creative Commons licences, for example 'Attribution 4.0 International': http://staging.creativecommons.org/licenses/by/4.0/legalcode [last accessed: 29 October 2013] 